\title{
PEMBAGIAN HAK ATAS TANAH WARIS DALAM HUKUM ADAT BALI
}

\author{
I Putu Angga Aptina, Anak Agung Istri Agung Desak Gde Dwi Arini \\ Fakultas Hukum Universitas Warmadewa, Denpasar-Bali, Indonesia \\ anggahihi14@gmail.com, notistria@yahoo.com, arinidesak@gmail.com
}

\begin{abstract}
Abstrak
Persoalan sengketa warisan di kalangan masyarakat desa sangat sering terjadi. Untuk itu perlu adanya hukum yang tertulis maupun tidak tertulis demi terselenggaranya pembagian harta warisan yang adil bagi setiap pihak Berdasarkan uraian latar belakang masalah maka tujuan penelitian adalah untuk memahami dan mendeskripsikan proses pembagian hak atas tanah waris dalam hukum adat Bali dan cara penyelesaian masalah atau sengketa yang terjadi. Adapun metode penelitian yang digunakan yaitu metode penelitian Empiris pendekatannya untuk melihat hukum dalam artian yang nyata atau dapat dikatakan melihat meneliti bagaimana bekerjanya hukum di masyarakat. Hasil penelitian menunjukkan Sebagai perwujudan sikap saling menghormati dan sikap hidup rukun maka penyelesaian sengketa diupayakan selalu melalui musyawarah secara kekeluargaan. Penyelesaian secara damai lebih diutamakan untuk menjaga keseimbangan dalam pergaulan hidup bermasyarakat. Penyelesaian secara damai juga dimaksudkan untuk menghilangkan rasa dendam akibat persengketaan yang timbul. Penyelesaian secara damai dalam kehidupan di desa dipandang sebagai hal yang perlu dan merupakan keharusan untuk menjaga kerukunan dalam penyelesaian sengketa. Diharapkan permasalahan dapat diselesaikan secara damai dengan cara kekeluargaan.
\end{abstract}

Kata Kunci: Hak atas tanah; Tanah waris; Hukum adat Bali

\begin{abstract}
The issue of inheritance disputes among the village community is very frequent. For this reason, written and unwritten laws are needed for the implementation of a fair distribution of inheritance for each people. The research method used is the Empirical research method, the approach is to see the law in a real sense or it can be said to see researching how the law works in society. The results showed that as a manifestation of mutual respect and an attitude of living in harmony, always strived for dispute resolution through family deliberations. Peaceful settlement is prioritized to maintain balance in social life. Peaceful resolution is also intended to eliminate feelings of resentment resulting from disputes that arise. Peaceful settlement in life in the village is seen as necessary and a necessity to maintain harmony in dispute resolution. It is hoped that the problem can be resolved amicably in a friendly manner.
\end{abstract}

Keywords: Land rights; Inherited land; Balinese customary law

\section{PENDAHULUAN}

Dalam kehidupan masyarakat desa yang penuh dengan kekerabatan dan kekeluargaan tidak menutup kemungkinan terjadi juga permasalahan-permasalahan yang berhubungan dengan kepentingan mereka sendiri di lingkungan perdata seperti masalah pembagian tanah warisan pembagian warisan lain yang sering menimbulkan sengketa dalam lingkungan keluarga mereka sendiri. Kekerabatan dan suasana hidup yang penuh kekeluargaan tidak akan dapat memberikan jaminan dalam lingkungan tersebut dapat terjaga untuk selalu hidup dengan suasana nyaman dan tentram.

Beragam permasalahan yang timbul dalam kehidupan masyarakat desa tersebut sudah pasti menghendaki pemecahan atau solusi yang secepat dan sesegera mungkin dalam rangka menjaga kenyamanan dan ketentraman keluarga itu sendiri. Tanggung jawab terhadap berbagai permasalahan yang timbul menyangkut kepentingan masyarakat desa tentu menjadi tanggungjawab dari Kepala Desa. Dengan demikian berbagai permasalahan yang timbul di desa tersebut idealnya Kepala Desa bertindak terlebih dahulu sebagai penengah atau wasit dalam menyelesaikan setiap sengketa yang terjadi. 
Khusus sengketa warisan yang sering muncul sebagai salah atau permasalahan yang terjadi di desa merupakan masalah yang menarik untuk dikaji lebih-lebih sudah menyangkut tentang pembagian warisan karena umumnya warisan mempunyai nilai ekonomis dan religius yang tinggi. Dengan kata lain warisan dapat menimbulkan kebahagian atau pihak dan di pihak lain dapat menimbulkan kesengsaraan apabila dalam atau dan pembagian tidak sesuai dengan ketentuan yang seharusnya diikuti bersama.

Penelitian terdahulu juga telah dijelaskan oleh (Febriawanti \& Mansur, 2020; Purnama, 2017), yang menyatakan bahwa dalam aturan adat Bali masyarakat menganut asas Kepurusa/Purusa, artinya keseluruhan tanggungjawab keluarga dan keturunannya berada di pundak laki-laik (purusa). Ketika anak laki-laki yang sulung berumah tangga dan hidup mandiri (menehan), ia memperoleh sepetak tanah untuk diolah sendiri sebagai bekal kehidupan keluarganya, begitu seterusnya ketika anak lakilaki yang lain berumah tangga. Proses penerusan harta warisan ini berjalan ketika pewaris masih hidup, terutama dalam harta warisan yang dapat dibagi-bagi secara individual. Agar tidak terjadi perselisihan antara ahli waris, maka harus menjalin keharmonisan dalam rumah tangga, sehingga tidak terjadi perebutan hak milik antara ahli waris yang ingin mendapatkan warisan. Adapun tujuan penelitian ini yaitu mengetahui proses pembagian hak atas tanah waris dalam hukum adat Bali dan mengetahui penyelesaian sengketa terhadap pembagian hak bersama yang telah disepakati oleh para ahli waris.

\section{METODE PENELITIAN}

Adapun metode yang digunakan dalam penelitian ini yaitu menggunakan metode Hukum Empiris. Dalam penelitian dengan menggunakan metode hukum empiris, dilakukan untuk melihat hukum dalam arti nyata atau dapat dikatakan melihat dan meneliti bagaimana bekerjanya hukum di masyarakat. Dalam penelitian ini data yang diperoleh berupa data primer dan data sekunder. Data primer yakni data yang diperoleh dari sumber data lapangan, sedangkan data sekunder diperoleh dari bahan -bahan hukum tertulis atau dokumen yang memuat informasi seperti buku, kamus, laporan penelitian sehubungan dengan pewarisan pada umumnya dan pada masyarakat adat Bali khususnya. Untuk mendapatkan data yang akurat, diperlukan teknik pengumpulan data yang digunakan dalam penelitian ini yaitu teknik wawancara (interview) yang berpedoman pada pedoman pertanyaan (interview guide). Setelah data yang diperlukan terkumpul, selanjutnya adalah tahap pengolahan dan analisis data. Dalam pengolahan dan analisis data dilakukan dengan metode yang bersifat kualitatif dilengkapi dengan analisis situasional.

\section{HASIL DAN PEMBAHASAN}

\section{Proses Pembagian Hak Atas Tanah Waris dalam Hukum Adat Bali}

Didalam Pewarisan berhubungan erat dengan hukum waris Hukum waris adalah kumpulan atau yang atau hukum mengenai kekayaan karena wafatnya seseorang yaitu mengenai pemindahan kekayaan yang ditinggalkan oleh si pewaris dan akibat dari pemindahan ini bagi orang-orang yang memperolehnya baik dalam hubungan antara mereka dengan mereka maupun dalam hubungan antara mereka dengan pihak ketiga. Adapun tiga kunci yang menjadi unsur-unsur pewarisan yaitu pewaris harta warisan dan ahli waris (Windia, 2006).

Hukum waris memberikan atau tentang apa yang akan diperbuat dengan kekayaan seseorang bilamana ia meninggal dunia. Pada dasarnya harta warisan mulai terbuka dan dapat dilakukan pembagian warisan oleh masing-masing ahli waris adalah pada saat pewaris meninggal dunia (Artadi, 2003).

Pemberian dari orang tua kepada anak adalah atau pembekalan untuk membentuk keluarga sendiri tetapi setelah orang tua (pewaris) meninggal harta yang telah diberikan akan diperhitungkan kembali sebagai harta peninggalan. Pemberian tanah kepada anak yang akan kawin merupakan atau pengoperan wajar dalam lingkungan kerabat.

Pewarisan adalah hubungan hukum atau kaidah hukum yang atau hubungan hukum antara pewaris dengan ahli warisnya atas harta warisan yang ditinggalkan baik setelah pewaris meninggal ataupun selagi pewaris itu masih hidup. Hubungan hukum ini merupakan kaidah-kaidah yang bersifat atau dan merupakan keadaan hukum yang mengakibatkan terjadinya perubahan hak dan peralihan dari atau bentuk ke bentuk yang lain dan merupakan atau proses yang harus dilakukan secara tepat dan berurutan. Proses yang dimaksud dalam hal ini adalah cara sebagai atau upaya yang sah dalam 
perubahan hak dan kewajiban atau harta warisan dan besarnya perolehan berdasarkan kedudukan para pihak karena ditentukan oleh hukum.

Pada umumnya hukum adat waris tidak menentukan kapan waktu diadakan pembagian Menurut ada kebiasaan waktu pembagian setelah pewaris wafat dapat dilaksanakan setelah upacara selamatan yang disebut tujuh hari empat puluh hari atau hari atau seribu hari Hal ini dimaksudkan para ahli waris berkumpul pada saat itu.

Hukum waris yang atau dalam buku Burgerlijk wetboek/Kitab Undang-undang Hukum Perdata mengenal hak tiap-tiap ahli waris atau bagian yang tertentu dari harta peninggalan Segala barang harta peninggalan itu merupakan atau atau abstrak yang dapat dinilai dengan sejumlah uang yang tertentu banyaknya dan tiap-tiap waktu yang dapat dibagi-bagi dalam pecahan berdasarkan ilmu berhitung menurut perhitungan pada waktu meninggalnya pewaris.

Perkawinan harta benda perkawinan pewarisan dan bahkan akibat yang ditimbulkan oleh ketiga peristiwa tersebut yaitu Sengketa kerap kali menjadi atau peristiwa yang sulit untuk dihindari atau kadang-kadang merupakan atau peristiwa yang dikehendaki. Adanya perkawinan yang dilakukan oleh setiap insan manusia merupakan langkah dalam hidup untuk memulai kehidupan yang baru. Adanya harta benda dalam perkawinan adalah sebagai akibat dari adanya perkawinan itu sendiri begitu pula timbulnya pewarisan dan Sengketa dalam pewarisan.

Dalam masyarakat Adat di Bali atau atau kedudukan hukum suami istri serta anak-anaknya yang dilahirkan dalam perkawinan tersebut sangat ditentukan oleh bentuk perkawinan yang ditempuh.

Dengan demikian keberadaan keturunan (anak) atau penerus dalam perkawinan adat Bali adalah sebagai ahli waris yang mewarisi dan melanjutkan atau meneruskan segala hak dan kewajiban yang dimiliki oleh orang tuannya dan leluhurnya secara turun temurun maupun yang ada dan diperoleh dari semenjak perkawinan orangtuanya.

Banyak barang-barang yang diwariskan oleh pewaris yang akan menjadi waris bagi para ahli waris yang meliputi barang-barang yang boleh dibagi-bagi ataupun yang tidak boleh dibagi-bagi yang penguasaannya harus bersama-sama atau salah seorang/beberapa orang dari ahli waris sebenarnya bukanlah perkara yang sulit jika para ahli waris mau dan mampu berkomunikasi sebagaimana asas dari pada hukum adatnya sendiri yaitu penyelesaian dengan kekeluargaan musyawarah dan menghormati permufakatan yang telah di sepakati Hak-hak pembagian waris pada zaman Bali Kuno sering disebut dalam prasasti khususnya pembagian harta waris dalam kehidupan berumah tangga (Agung, 2016).

Maka proses pembagian hak atas tanah waris dalam Hukum Adat Bali dapat dilakukan dengan dua cara yaitu :

1. Proses pembagian hak atas tanah waris dilakukan pada saat pewaris masih hidup dilakukan oleh pewaris langsung dengan membagikan kepada para ahli warisnya dengan pembagian sebagaimana yang dianggap adil oleh pewaris semasa hidupnya tersebut.

2. Proses pembagian hak atas tanah waris dilakukan setelah pewaris meninggal dunia dilakukan oleh para ahli waris dengan cara pembagian yang sama antara para ahli waris atau berdasarkan kesepakatan para ahli waris.

\section{Penyelesaian Sengketa terhadap Pembagian Hak Bersama yang Telah Disepakati oleh Para Ahli Waris}

Apabila atau perbuatan yang tidak sesuai dengan norma-norma maupun kaidah- kaidah yang berlaku dalam masyarakat itu apabila dilanggar tentu akan menimbulkan konflik atau Sengketa. Menurut (Samosir, 2013) yang dimaksud dengan konflik adalah gejala yang ada di setiap masyarakat dan karena itu konflik dapat dipandang sebagai hakikat perbedaan dari kepentingan yang berbeda sehingga dalam menciptakan keseimbangan di antara kepentingan yang berbeda-beda merupakan tugas pokok dari hukum itu sendiri.

Setiap orang pada hakikatnya menginginkan hidup yang damai dan selalu berdamai dengan setiap orang. Namun demikian sulit juga menghindari terjadinya Sengketa di antara orang-orang itu sendiri Sengketa terjadi dikarenakan konflik antara orang perorangan atau perorangan dengan dua pihak atau lebih sebagai akibat dari adanya perbedaan-perbedaan baik mengenai atau nilai-nilai perbedaan pendapat maupun perbedaan kepentingan Pada masyarakat hukum adat di Bali. Sengketa yang terjadi dikarenakan adanya persoalan-persoalan atau permasalaan-permasalahan adat yang dapat 
dikualifikasikan sebagai Sengketa adat dan agama menjadi kewenangan pengurus Desa Pakraman (Prajuru Desa Pakraman) untuk menyelesaikannya.

Apabila terjadi Sengketa sebagaimana tersebut diatas biasanya pertama-tama diusahakan diselesaikan melalui perdamaian yang melibatkan prajuru adat seperti oleh Kelian Banjar Adat Bendesa Adat (kepala desa adat) dengan melibatkan Perebekel (Kepala Desa Dinas) dan bahkan apabila tidak mampu diselesaikan secara damai sampai melibatkan pejabat seperti Camat Bupati DPRD dan Gubernur untuk memfasilitasi tercapainya perdamaian.

Koesno (1974) mengatakan bahwa dalam praktik tidak sedikit yang meragukan kemampuan hukum adat dalam mengenai persoalan-persoalan yang diajukan ke Pengadilan System kodifikasi selain dasar-dasarnya mudah diketahui unsur-unsur dari atau tindakan sudah jelas dalam atau undangundang. Hakim tinggal menerapkan saja apakah syarat-syarat dari unsur-unsur atau perbuatan itu telah terpenuhi atau tidak. Dari situlah dapat dilihat dan menjadi dasar atau putusan apakah perbuatan itu dilarang oleh undang-undang atau tidak Lain halnya dengan hukum adat sebagaian besar tidak tertulis kaidah-kaidah substansinya masih tidak jelas apakah hukum adat mengenal kaedah substantif oleh ilmu pengetahuan sendiri dengan sangan hati-hati masih dipertentangkan (Koesno, 1974).

Dalam praktik penyelenggaraan pemerintahan ternyata tujuan hukum tampaknya hanya untuk menjadi kepastian hukum belaka sehingga kurang memperhatikan aspek keadilan dan manfaatnya. Oleh karena itu penerapan hukum yang hanya menekankan pada aspek kepastian hukum belaka menyebabkan masyarakat pencari keadilan merasa tidak puas sehingga upaya penyelesaian konflik yang terjadi dalam masyarakat tidak tuntas (Sirtha, 2004).

Lembaga peradilan baik peradilan di tingkat desa maupun melalui peradilan Negara seharusnya menjadi pilihan terakhir bagi setiap individu maupun masyarakat di dalam menyelesaikan sengketa itu berarti di harapkan setiap sengketa yang terjadi diantara mereka hendaknya selalu dapat diselesaikan melalui jalur perdamaian dengan musyawarah dan mufakat. Hal ini sesuai dengan asas hukum adat yaitu menyelesaikan setiap Sengketa waris dilakukan dengan berasakan musyawarah dalam suasana kekeluargaan kebersamaan dengan suasana yang rukun damai dan pembagian warisan yang sesuai dengan rasa atau dan berkeadilan.

Dalam kehidupan masyarakat di Bali Sengketa tentang warisan menjadi hal yang sering dijumpai dalam kehidupan di masyarakat karena erat kaitannya dengan proses warisan Tanggungjawab dan hak waris pada setiap ahli waris dalam hukum waris adat bali tidak dapat dilepaskan begitu saja. Dalam hukum waris bagi masyarakat adat di Bali pembagian warisan lebih mengutamakan anak laki-laki Anak laki-laki dalam setiap keluarga memiliki tanggungjawab dan hak dalam perolehan warisan. Tanggungjawab itu sendiri berupa ayahan yang harus dilakukan seperti berupa ayahan desa ayahan karang dan tanggungjawab mengurus dan melanjutkan persembahan kepada leluhur melalui upacara yang dilakukan di merajan atau sanggah masing- masing dan hak yang diperoleh berupa warisan tanah yang diwariskan oleh pewaris dengan adanya pewarisan yang diperoleh untuk menjaga dan meneruskan kelangsungan hidup dalam melaksanakan tanggung jawab dan hak yang melekat pada ahli waris.

Walaupun pewaris di masa hidupnya telah mengadakan pembagian waris untuk segenap para ahli waris namun, pembagian yang telah disepakati oleh pewaris dan para ahli waris dapat juga menimbulkan sengketa.

Dengan Kelihan Adat Desa Sayan Delodan Werdi Bhuwana Mengwi Badung Dengan Bapak I Ketut Umara Sebagaimana yang dialami antara Made Sruta dan I Nyoman Sapta Mereka berdua adalah anak-anak dari Ketut Muliana Pembagian waris yang dilakukan pada saat pewaris masih hidup (Ketut Muliana) meliputi pula pengalihan atas jabatan adat atau harta kekayaan kepada ahli waris. Pembagian ini dilakukan karena pewaris telah berusia lanjut dan anak (ahli waris) sebagaimana tersebut telah mantap berumah tangga sehingga pewaris pun siap membagikan warisannya semasa hidup pewaris. Pewarisan terutama kepada anak laki-laki tertua menurut prinsip patrilineal. Pewaris melakukan pembagian sebesar 60\% kepada Made Sruta dan sebesar 40\% kepada I Nyoman Sapta terhadap harta kekayaan yang bersifat materiil pembagian ini dilakukan mengingat pewaris melihat Made Sruta dianggap mampu melanjutkan dan meneruskan tanggung jawab pewaris untuk meneruskan dan merawat harta pusaka termasuk mengurus kewajiban di merajan apabila pewaris telah meninggal dunia. Dilihat dari lebih besarnya warisan kepada Made Sruta memiliki tanggung jawab besar pula sesuai dengan perolehan yang diterimanya. Dari tanggung jawab yang diberikan pewaris dan telah disepakati dan diterima oleh para ahli waris dan apa yang telah dibagikan tersebut 
merupakan atau hal yang adil bagi pewaris dan para ahli waris tidak boleh menolak ataupun keberatan atas apa angah telah dibagikan oleh pewaris. Hal ini dikarenakan dalam hukum adat bali apa yang telah dikehendaki oleh pewaris haruslah dihormati dan dilaksanakan sebagai hukum/ketentuan yang mengikat bagi para ahli warisnya. Karena keputusan pewaris yang dilaksanakan oleh para ahli waris adalah wujud bhakti (penghormatan).

Namun kemudian ketika pewaris meninggal ahli waris yang bernama I Nyoman Sapta merasa bahwa pembagian waris yang dilakukan si pewaris semasa hidupnya tidak adil. Kemudian I Nyoman Sapta mempersengketakan kembali pembagian yang telah disepakati semasa hidup pewaris yang dirasa tidak adil. Adapun yang Sengketa adalah sebidang tanah yang merupakan pembagian yang telah diterima oleh Made Sruta Sengketa tersebut berawal dari di atas sebidang tanah yang merupakan bagian warisan Made sruta tersebut ingin dimanfaatkan dengan membangun ruko oleh Made Sruta Atas hal tersebut I Nyoman Sapta keberatan karena menurut I Nyoman Sapta Made Sruta telah mendapatkan bagian terlalu banyak dan I Nyoman Sapta ingin tanah tersebut menjadi bagiannya padahal tanah tersebut adalah bagian warisan yang diterima Made Sruta yang dibagikan oleh pewaris semasa hidupnya. Dari sinilah bermula Sengketa antara para ahli waris atas Sengketa sebagaimana tersebut di atas salah atau ahli waris yaitu Made Sruta berinisiatif melalukan musyawarah dengan I Nyoman Sapta dengan bertujuan untuk dapat menyelesaikan Sengketa yang dipermasalahkan oleh I Nyoman Sapta setelah musyawarah dilakukan dan tidak mencapai kata sepakat Made Sruta meminta bantuan dari Prajuru desa sebagai pengemong masyarakat desa untuk membantu memediasi Sengketa yang dihadapi oleh ahli waris supaya mencapai kata sepakat dan penyelesaian secara damai Hasil Penelitian cara penyelesaian sengketa dengan kelihan adat Br Sayan Delodan Werdi Bhuwana mengwi ini dilakukan secara musyawarah yang dalam prosesnya.

1. Terjadinya musyawarah secara internal (kekeluargaan) antara para pihak dengan tujuan terjalinya kesepakatan dalam penyelesaian Sengketa pembagian hak bersama yang telah disepakati oleh para ahli waris. Namun apabila tidak adanya kesepakatan antara para pihak para pihak bias mendatangkan prajuru desa (klian desa) sebagai mediator yang sebagai penengah atau sebagai pemediasi diantara para pihak.

2. Prajuru desa (klian desa) sebagai penengah dalam Sengketa ini atau berperan sebagai mediator untuk memediasi para pihak agar dapat menyelesaikan permasalahan diantara para pihak dan mencapai kesepakatan diantara para pihak untuk tercapainya kedamaian dan ketenteraman antara para pihak. Setelah dilakukan mediasi dengan beberapa tahapan dan proses maka kata sepakatpun tercapai yaitu dengan membuat atau kesepakatan damai dan menyepakati bahwa apa yang telah dibagikan oleh pewaris semasa hidupnya sebagaimana tersebut di atas akan dilaksanakan oleh pewaris.

\section{SIMPULAN DAN SARAN}

\section{Simpulan}

Proses pembagian hak atas tanah waris dalam hukum adat bali dapat dilakukan dengan dua cara yaitu proses pembagian hak atas tanah waris dilakukan pada saat pewaris masih hidup dilakukan oleh pewaris langsung dengan membagikan kepada para ahli warisnya dengan pembagian sebagaimana yang dianggap adil oleh pewaris semasa hidupnya tersebut dan proses pembagian hak atas tanah waris dilakukan setelah pewaris meninggal dunia dilakukan oleh para ahli waris dengan cara pembagian yang sama antara para ahli waris atau berdasarkan kesepakatan para ahli waris.

Penyelesaian Sengketa terhadap pembagian hak bersama yang telah disepakati oleh para ahli waris maka sengketa tersebut akan diselesaikan dengan upaya musyawarah diantara para pihak yang bersengketa maupun dengan melibatkan prajuru desa untuk turut serta membantu penyelesaian Sengketa tersebut Namun demikian apabila penyelesaian tersebut tidak dapat berjalan sebagaimana yang diharapkan maka prajuru desa akan menyerahkan Kembali kepada para pihak untuk menempuh jalur hukum sebagaimana yang dikehendaki para pihak sehingga pembagian hak Bersama yang telah disepakati oleh para ahli waris sebelumnya dapat memperoleh kepastian hukum

\section{Saran}

Hendaknya proses pembagian hak atas waris baik yang dilakukan oleh pewaris semasa hidupnya maupun pembagian yang dilakukan antara para ahli waris setelah pewaris meninggal dunia pembagiannya dilakukan dengan membuat akta pembagian hak waris dalam bentuk akta otentik 
sehingga terjaminya kepastian hokum. Perlunya sosialisasi tentang hukum waris adat Bali kepada masyarakat hukum adat Bali pada umumnya oleh atau baik itu prajuru desa pemerintah (negara) maupun akademisi sehingga dapat meminimal atau menghindari terjadinya Sengketa terhadap pembagian hak waris.

\section{DAFTAR PUSTAKA}

Agung, A. A. I. (2016). Makna Purusa Dan Pradana Dalam Putusan Hakim Mengenai Sengketa Warisan Adat Bali. Udayana University Press.

Artadi, I. K. (2003). Hukum Adat Bali dengan Aneka Masalahnya. Pustaka Bali Post.

Febriawanti, D., \& Mansur, I. A. (2020). Dinamika Hukum Waris Adat di Masyarakat Bali pada Masa Sekarang. Media Iuris, 3(2), 119.

Koesno, M. (1974). Tentang Tiga Asas - asas Kerja untuk Menghadapi Perkara - Perkara Hukum Adat di Indonesia dalam Lima Puluh Tahun Pendidikan Hukum di Indonesia. Fakultas Hukum Universitas Indonesia.

Purnama, N. M. N. I. (2017). Pewarisan Hak Milik Atas Tanah Menurut Hukum Adat Bali. Jurnal Kertha Wicaksana, 1(1).

Samosir, D. (2013). Hukum Adat Indonesia: Eksistensi dalam Dinamika Perkembangan Hukum di Indonesia. Nuansa Aulia.

Sirtha, I. N. (2004). Aspek Hukum Adat Dalam Konflik Adat Di Bali. Udayana University Press.

Wayan P Windia, K. S. (2006). Pengantar Hukum Adat Bali Lembaga Dokumentasi dan Publikasi. Fakultas Hukum Universitas Udayana. 